\title{
TK Gene
}

National Cancer Institute

\section{Source}

National Cancer Institute. TK Gene. NCI Thesaurus. Code C20224.

The TK Gene encodes thymidine kinase, a transferase class pyrimidine salvage enzyme that catalyzes ATP-dependent phosphorylation of thymine deoxyribonucleoside. The TK gene and promoter are used widely in genetic research because of the easily selectable phenotype. 